\title{
Perkembangan Sosial dan Emosional Anak Usia Dini
}

${ }^{1}$ Nurhasanah, ${ }^{2}$ Suci Lia Sari, ${ }^{3}$ Nova Adi Kurniawan

${ }^{1}$ STAI Auliaurrasyidin, Tembilahan, Riau, Indonesia

${ }^{2}$ STAI Auliaurrasyidin, Tembilahan, Riau, Indonesia

${ }^{3}$ STAI Auliaurrasyidin, Tembilahan, Riau, Indonesia

\section{INFORMASI \\ ARTIKEL}

Artikel Histori:

Diterima :

$14 / 06 / 2021$

Direvisi :

20/07/2021

Diterbitkan:

31/07/2021

\section{Keywords: \\ Social, \\ Emotional, \\ Early Childhood}

\section{Kata Kunci:}

Sosial,

Emosional,

Anak Usia Dini

\section{DOI:}

https://doi.org /10.46963/mas h.v4i02.346

\begin{tabular}{l} 
Korespondensi \\
Penulis: \\
Nurhasanah \\
nurhasanah5079 \\
\hline 8@gmail.com
\end{tabular}

ABSTRACT: The undeveloped social and emotion of early childhood, especially group B students of Kindergarten As-Salam Pekan Arba Tembilahan takes a serious teachers intention since it is one of many success factors in the future. There needs an extraefforts to develop from teachers. This research is to discover the teachers' efforts and factors that follow the development of socialemotional of group B students of TK As-Salam Pekan Arba Tembilahan. This is qualitative descriptive research. The data were collected over interviews, observation, and documentation. The data analyzing technique was triangulation data. The findings showed that the teacher already did many efforts to develop the students' social and emotions, such as (1) putting attention to them, (2) introducing positive and negative, and its impact on storytelling, (3) giving a comfort zone, (4) practicing positive attitude in the school, (5) reinforcing students by giving salutations and rewards, (6) giving facilities to choose and actualize their hobby, and (7) doing communication between teacher and students.

ABSTRAK: Belum berkembangannya sosial emosional anak usia dini, terutama kelompok B TK As-Salam Pekan Arba Tembilahan menjadi perhatian serius bagi guru karena ia menjadi salah satu faktor kesuksesan anak di masa depan. Oleh sebab itu, perlu usaha ekstra dari guru untuk mengembangkannya. Penelitian ini bertujuan untuk mengetahui upaya guru dan faktor yang menyertai pengembangan sosial emosional anak kelompok B TK As-Salam Pekan Arba Tembilahan. Penelitian ini adalah penelitian deskriptif kualitatif. Pengumpulan data menggunakan wawancara, observasi dan dokumentasi. Teknik analisis data teknik tringgulasi data. Hasil temuan menunjukkan bahwa guru telah melakukan berbagai macam upaya untuk mengembangkan sosial emosional anak kelompok B TK As-Salam Pekan Arba Tembilahan, seperti: (1) memberi perhatian, (2) mengenalkan bentuk emosi dan dampaknya melalui cerita, (3) memberi rasa aman, nyaman, dan kasih sayang, (4) pembiasaan perilaku positif di sekolah, (5) memberi penguatan dengan pujian dan penghargaan, (6) memberi fasilitas untuk memilih dan mengaktualisasikan kegemaran, dan (7) menjalin komunikasi dengan siswa.

\section{Cara mensitasi artikel:}

Nurhasanah, Sari, S. L., \& Kurniawan, N. A. (2021). Perkembangan Sosial dan Emosional Anak Usia Dini. Mitra Ash-Shibyan: Jurnal Pendidikan dan Konseling, 4(02), 91-102. https://doi.org/10.46963/mash.v4i02.346 


\section{PENDAHULUAN}

Anak usia dini adalah individu yang unik dengan segenap potensi yang ia miliki. Saat anak dilahirkan, ia belum bersifat sosial. Artinya, ia belum memiliki kemampuan untuk bergaul dengan orang lain. Sehingga ia membutuhkan bimbingan dan didikan orang lain terutama orang tua sebagai orang terdekatnya. Sutarman dan Asih (2016) menegaskan bahwa sejak lahir seorang anak harus sudah diasuh dan dibimbing agar tumbuh dan berkembang sesuai yang diinginkan pada kemudian hari. Kaitanya dengan itu, Undang-Undang Nomor 20 Tahun 2003 tentang Sistem Pendidikan Nasional Pasal 1 Nomor 14 dalam Latif \& dkk (2013) menegaskan bahwa:

\section{"Pendidikan anak usia dini (PAUD) adalah suatu upaya pembinaan yang ditujukan kepada anak sejak lahir sampai dengan usia enam tahun yang dilakukan melalui pemberian rangsangan pendidikan untuk membantu pertumbuhan dan perkembangan jasmani dan rohani, agar anak memiliki kesiapan dalam memasuki pendidikan lebih lanjut, baik pendidikan secara formal disekolah maupun secara nonformal."}

Masa usia dini merupakan masa emas, dimana pada masa ini anak sedang mengalami proses pertumbuhan dan perkembangan yang luar biasa. Karena pada masa ini pula, anak belum memiliki pengaruh negatif yang banyak dari luar atau lingkunganya. Dengan kata lain, orang tua maupun pendidik akan lebih mudah mengarahkan anak menjadi lebih baik. Anak usia dini merupakan masa yang sangat cermerlang untuk dilakukan dan diberikan pendidikan.

Anak usia dini sering disebut juga dengan anak usia prasekolah yang hidup pada masa kanak-kanak awal dan masa peka. Pada masa ini, Yusuf (2016) menjelaskan bahwa anak berada pada fase perkembangan individu. Artinya, seluruh potensi yang dimiliki oleh anak siap untuk dikembangkan. Wiyani (2014) menegaskan, "masa ini merupakan masa yang paling tepat untuk meletakkan dasar pertama dan utama dalam mengembangkan berbagai potensi serta kemampuan fisik, kognitif, bahasa, sosial dan emosional serta agama dan moral." Oleh sebab itu, orang tua dan pendidik harus dapat bersinergi dan bekerjasama untuk dapat mengembangkan potensi-potensi yang ada pada diri anak. Salah satu potensi dan kemampuan anak yang perlu dikembangkan oleh pendidik dan orag tua adalah potensi dan kemampuan sosial dan emosional anak.

92 mitra Ash-Shibyan: Jurnal Pendidikan dan Konseling | Vol. 4, No. 02 (2021) Licensed under CC-BY-SA c) (1) (2) 
Pada dasarnya, setiap anak tidak akan terlepas dari perkembangan sosial emosional. Terkadang perkembangan sosial emosional anak seringkali dikesampingkan oleh orang tua dan guru. Akibatnya, tidak jarang anak seusia mereka seringkali merasa marah dan emosi ketika tidak diperbolehkan oleh guru untuk tidak bermain saat proses pembelajaran, ingin menang sendiri dan main sendiri, sibuk dengan dunianya, dan seringkali terdapat anak yang agak lebih aktif secara fisik dari yang lain sehingga guru terfokus padanya dan proses pembelajaran tidak kondusif. Hal ini termasuk ekspresi emosi anak yang sangat wajar, namun jika dibiarkan maka akan berakibat munculnya prilaku negatif pada anak. Anak yang sehat pada emosi adalah anak yang mampu mengungkapkan ekspresinya secara positif. Agar anak mampu mengungkapkan secara positif, maka guru perlu mengembangkan kemampuan perkembangan sosial emosional pada anak sejak usia dini.

Perkembangan sosial emosional merupakan perubahan perilaku yang disertai dengan perasaan-perasaan tertentu yang datang dari hati, yang melingkupi perkembangan sosial emosional merupakan perubahan perilaku yang disertai dengan perasaan-perasaan tertentu yang melingkupi anak usia dini saat berhubungan dengan orang lain (Wiyani, 2014; Khairiah, 2018). Sejalan dengan itu, Khaironi (2018) menjelasakan, perkembangan sosial merupakan peningkatan kemampuan individu dalam berinteraksi dengan orang lain. Sementara itu, ia melanjutkan, perkembangan emosional adalah kemampuan individu untuk mengelola dan mengekspresikan perasaannya dalam bentuk ekspresi tindakan yang dinampakkan melalui mimik wajah maupun aktivitas lainnya (verbal atau non verbal) sehingga orang lain dapat mengetahui dan bahkan memahami kondisi atau keadaan yang sedang dialaminya. Oleh sebab itu, perkembangan sosial emosional tidak dapat dipisahkan satu sama lain karena saling berhubungan dengan interaksi antara individu dengan individu atau individu dengan society.

Perkembangan sosial emosional sangat penting keberadaannya pada diri seseorang karena hubungannya dengan kemampuan anak dalam menjalin interaksi dengan orang lain. Terlebih ketika berada di sekolah, anak akan melakukan banyak interaksi secara langsung kepada guru dan teman-temannya, sehingga akan menstimulasi perkembangan sosial emosionalnya (Bakken et al. dalam Wulandari \& Purwanta (2021)). Jika anak tidak memiki kompetensi sosial, maka anak bisa dibanyangkan

mitra Ash-shibyan: Jurnal Pendidikan dan Konseling | Vol. 4, No. 02 (2021) 93 Licensed under CC-BY-SA CC) (1) (2) 
bagaiamana anak akan membangun karirnya di kemudian hari. Begitupula dengan emosional anak, emosional anak perlu dikembangkan ke arah yang positif sehingga anak mampu mengekspresikan emosi sesuai dengan harapan lingkungan agar dapat diterima oleh komunitas dimana anak berada (Khaironi, 2018).

Oleh karenanya, sinergi atau kerjasama antara guru dan orang tua sangat diperlukan, karena mereka dapat membantu anak untuk mengelola emosi (Sukatin, et al., 2019). Saat di sekolah, guru sebagai orang tua kedua bagi anak sangat perlu memperhatikan dan mengambangkan potensi dan kemampuan sosial dan emosional anak karena proses sosialemosi, melibatkan perubahan dalam hubungan dengan seseorang dengan orang lain, perubahan emosi, dan perubahan dalam kepribadian.

Kaitannya dengan pentingnya tumbuh-kembang sosial emosional anak usia dini sebagaimana dijelaskan oleh (Syafi'i \& Solichah, 2021), tulisan ini bertujuan untuk memberikan gambaran upaya yang dapat guru lakukan dalam mengembangkan sosial dan emosional anak usia dini pada kelompok B TK As-Salam Pekan Arba Tembilahan.

\section{METODE PENELITIAN}

Penelitian ini adalah penelitian deskriptif dengan pendekatan kualitatif. Penelitian ini dilaksanakan di TK As-Salam Pekan Arba Tembilahan, Kecamatan Tembilahan, Kabupaten Indragiri Hilir, Provinsi Riau. Subyek dalam penelitian in adalah guru kelas B1, B2, dan B3, dan upaya guru dalam mengembangkan sosial emosional anak kelompok B di TK As-Salam Pekan Arba Tembilahan sebagai obyek penelitian. Informan dalam penelitian ini 3 guru kelas B, kepala sekolah, ketua yayasan, dan anak didik. Data dikumpulkan menggunakan teknik wawancara terstruktur (structure interview), observasi, dan dokumentasi. Data kemudian dianalisis menggunakan metode triangulasi data model Miles Huberman dengan tiga tahapan, yaitu data reduction, data display, dan conclusion drawing/verification.

\section{HASIL DAN PEMBAHASAN}

Merujuk kepada hasil wawancara, diketahui bahwa para pendidik TK As-salam Pekan Arba Tembilahan telah melakukan pembiasaanpembiasaan baik agar potensi dan kemampuan sosial dan emosional anak dapat berkembang. Pernyataan tersebut didukung oleh beberapa sumber data lain, seperti observasi dan dokumentasi. Di antara pembiasaan-

94 mitra Ash-Shibyan: Jurnal Pendidikan dan Konseling | Vol. 4, No. 02 (2021) Licensed under CC-BY-SA C) (;) (2) 
pembiasaan yang dilakukan pendidik agar potensi dan kemampuan sosial dan emosional anak dapat berkembang adalah dengan memberikan perhatian kepada anak, mengenalkan berbagai emosi positif dan negatif beserta dampaknya, memenuhi kebutuhan anak, menciptakan perilaku positif pada anak, memberikan reinforcement terhadap perilaku anak, memberikan kesempatan kepada anak untuk bermain, memilih dan mengaktualisasikan kegemarannya, menjalin komunikasi yang baik (Nuraeni, 2014; Mukhlish \& Mbelo, 2019; Sukatin, et al., 2019; Syafi'i \& Sholichah, 2021; Hikmah, Syaprudin, \& Jannah, 2021).

\section{Memberikan Perhatian Kepada Anak}

Berdasarkan hasil wawancara, observasi, dan didukung dengan hasil dokumentasi diketahui bahwa dalam memberikan perhatian kepada anak, guru menanggapi celotehan, menjadi pendengar, memberikan reward, bersikap ramah, menyapa, tersenyum, memberikan arahan, menyentuh, dan memberikan pelukan kepada anak. Bentuk perhatian tersebut disinyalir dapat mempengaruhi tumbuh kembang anak usia dini secara psikologis, terlebih pada perkembangan sosial dan emosional anak usia dini. Tidak hanya sosial dan emosional anak yang mendapatkan pengaruh, hasil belajarnya pun akan turut terkena dampaknya, sebagaimana penelitian yang dilakukan oleh Djafar, Pasongli, Robo, \& Tolangara (2020) bahwa perhatian orang tua memberikan dampak yang besar terhadap keberhasilan anak. Semakin tinggi perhatian orang tua, semakin tinggi pula prestasi belajar anak.

Perhatian merupakan kegiatan yang dilakukan seseorang dalam hubungannya pemilihan rangsangan yang datang dari lingkungannya (Slameto dalam Hikmah, Syaprudin, \& Jannah (2021)). Sejalan dengan itu, Wiyani (2014) menjelaskan, perhatian dapat dilakukan dengan menanggapi dan memahami berbagai perasaan yang melingkupi anak seperti menyapa anak, tersenyum kepadanya serta menanyakan berbagai kegiatan yang telah, sedang, dan yang akan dilakukannya. Jayanti dalam Hikmah, Syaprudin, \& Jannah (2021) menegaskan bentuk perhatian yang dapat dilakukan diantaranya adalah dengan memberikan fasilitas belajar, memberi nasehat, memberikan motivasi dan penghargaan, memenuhi kebutuhan anak, dan pengawasan terhadap anak.

mitra Ash-Shibyan: Jurnal Pendidikan dan Konseling | Vol. 4, No. 02 (2021) 95 Licensed under CC-BY-SA (c) (i) (2) 


\section{Mengenalkan Berbagai Emosi Positif dan Emosi Negatif Beserta Dampaknya Pada Anak}

Pengenalan emosi dan dampaknya kepada anak juga perlu dilakukan oleh guru agar anak mengetahui dan mengerti berbagai bentuk emosi beserta dampaknya. Karena emosi memegang peran penting dalam kesuksesan seseorang (Admin, 2020). Wiyani (2014) menegaskan, pengenalan emosi dan dampaknya kepada anak dapat dilakukan melalui cerita bergambar, video, dan pemberian nasehat. Emosi, terutama emosi negatif, akan memberikan dampak tidak diterimanya anak di lingkungannya. Sehingga, pola emosi yang diajarkan kepadanya akan membekas dan membawa dampak yang serius terhadap perkembangan emosinya (Marliani, 2015).

\section{Memenuhi Kebutuhan Anak}

Memenuhi kebutuhan anak (Jayanti dalam Hikmah, Syaprudin, \& Jannah (2021)) merupakan salah satu bentuk perhatian guru dan atau orang tua yang harus dilakukan. Kebutuhan setiap individu dapat berbeda antara satu sama lain. Kebutuhan yang sering kali anak usia dini butuhkan adalah kebutuhan akan rasa aman, nyaman, dan kasing sayang. Teori hirarki kebutuhan menurut Abraham Maslow menyatakan bahwa terdapat lima kebutuhan fisiologis, kebutuhan akan rasa aman, kebutuhan akan memilikinya, serta kebutuhan untuk dapat mengaktualisasikan diri (Marliani, 2015).

Sejalan dengan itu, Wiyani (2014) menegaskan apabila kebutuhan anak sudah dipenuhiseperti menjadikan anak merasa aman dan nyaman yang dapat menjadikan anak menampilkan emosi-emosi positif. Rasa nyaman itulah yang harus pertama kali diciptakan oleh seorang guru untuk memenuhi kebutuhan rasa aman bagi anak, karena setiap anak memiliki kebutuhan yang harus dipenuhi oleh guru. Untuk itu, seorang guru PAUD (Fakhruddin, 2018) harus memiliki tujuan dan strategi bagaimana membuat anak-anak bisa tumbuh dan berkembang menjadi pribadi-pribadi yang berpikir positif, bersikap optimis, memiliki kepercayaan diri, dan selalu menebar keindahan dan kemuliaan di mana pun mereka berada.

\section{Menciptakan Perilaku Positif Pada Anak}

Pembiasaan-pembiasan positif yang dilakukan oleh guru diharapkan agar anak memiliki perilaku positif. Merujuk kepada hasil penelitian, guru kelompok B TK As-Salam Pekan Arba Tembilahan telah

96 mitra Ash-Shibyan: Jurnal Pendidikan dan Konseling | Vol. 4, No. 02 (2021) Licensed under CC-BY-SA c) (1) (2) 
melaakukan pembiasaan-pembiasaan positif kepada anak seperti mengucap salam, membaca do'a, dan melalui metode cerita. Ngalim Purwanto dalam (Wiyani, 2014) menjelaskan, pembiasaan merupakan salah satu alat pendidikan yang sangat penting, terutama bagi anak-anak yang masih kecil, seperti anak usia dini. Pembiasaan yang baik penting artinya bagi perkembangan sosial emosional anak dan juga akan sangat berpengaruh kepada anak sampai hari tuanya. Marliani (2015) turut menegaskan bahwa pola emosi yang diajarkan orang tua dan/ atau guru kepada anak-anaknya akan membawa dampak terhadap perkembangan emosinya. Oleh sebab itu, peran seorang guru sebagai orang tua kedua bagi anak sangat krusial dalam menciptakan perilaku positif anak yang dampaknya akan terlihat saat usia mereka bertambah.

\section{Memberikan Reinforcement Terhadap Perilaku Anak}

Reinformcement atau pemberian penguatan juga perlu dilakakukan oleh guru sebagai bentuk apresisasi atas apa yang telah dilakukan anak. Reinforcement dapat berupa materi (seperti makanan) maupun non materi (seperti pujian) (Wiyani, 2014; Marliani, 2015). Hasil penelitian menunjukan bahwa guru telah melakukan reinforcement kepada anak dengan memberikan pujian, hadiah atau reward dan memberikan jempol kepada anak. Dengan reinforcement terlebih jika ada reward, anak merasa diperhatikan dan dihargai oleh guru, karena reward dalam pendidikan (Puspitasari, 2015) dinilai begitu tinggi. Selain itu, reward atau penghargaan merupakan salah satu bentuk perhatian guru terhadap anak (Jayanti dalam Hikmah, Syaprudin, \& Jannah (2021)), karena dengannya akan mendekatkan hubungan anak dengan guru.

\section{Memberikan Kesempatan Kepada Anak Untuk Memilih dan Mengaktualisasikan Kegemarannya}

Memberikan kesempatan kepada anak untuk memilih dan mempraktekkan kesukaannya merupakan fasilitas belajar yang diberikan oleh guru agar potensi dan kemapuan anak dapat berkembang, terutama potensi dan kemampuan sosial emosional (Jayanti dalam Hikmah, Syaprudin, \& Jannah (2021)). Dalam memberikan fasilitas belajar ini kepada anak, berdasarkan hasil penelitian, guru memberikan kesempatan/kebebasan dalam memilih permainan ketika jam pulang sekolah dan ketika kegiatan pembelajaran sedang berlangsung.

Sejalan dengan pendapat di atas, Wiyani (2014) bahwa orang tua atau guru PAUD malah harus memberikan kesempatan kepada anak 
untuk memilih dan mengaktualisasikan kegemarannya tersebutlah anak dapat menstabilkan perkembangan emosi pada anak. Berbagai emosi positif juga muncul manakala anak dapat melakukan kegemarannya, seperti rasa senang, ceria, bahagia, puas, dan lainnya (Marliani, 2015).

\section{Menjalin Komunikasi dengan Anak}

Dalam menciptakan rasa aman dan nyaman dalam belajar, seyogyanya guru dan atau orang tua membuka pintu komunikasi seluasluasnya kepada anak (Wiyani, 2014). Hal ini bertujuan unuk mengakomodir atau menampung aspirasi dari anak atau dapat juga digunakan sebagai momen untuk menyampaikan nasehat kepada anak. Dengan terjalinnya komunikasi yang baik antara guru dan anak, maka nasehat yang diberikan akan mudah dipahami oleh anak.

Merujuk kepada hasil penelitian, menjalin komunikasi dengan anak dapat dilakukan dalam berbagai bentuk, diantaranya adalah menyapa anak, memberikan cerita singkat dan memberikan tanya jawab kepada anak. Marliani (2015) menjabarkan, pada saat anak mengiginkan sesuatu, tanyakanlah kepada anak mengapa ia menginginkannya. Pada saat anak melakukan suatu kegiatan, tanyakanlah apa yang telah ia dapatkan dari kegiatannya.

\section{Memberikan Contoh Perilaku Yang Baik}

Anak usia dini dengan kelebihannya dalam merekam informasi akan merekam semua aktivitas orang lain, termasuk guru dan orang tua. Hasil rekaman informasi tersebut kemudian cepat atau lambat akan diaktualisasikannya dalam bentuk perilaku atau sikap. Karena pada masa ini anak akan dapat dengan mudah meniru, melakukan persaingan, kerja sama, simpati, empati, hubungan sosial, membagi, dan perilaku akrab (Marliani, 2015). Dampak dari itu, guru sebagai orang tua kedua anak di sekolah harus dapat berperan sebagai figur teladan yang baik yang akan dicontoh oleh anak, karena pada hakikatnya guru adalah seseorang yang digugu dan ditiru (Sulhan dalam Nuraeni, 2014; Djamarah dalam Ghofar, 2017). Guru harus menjadi suri teladan terutama bagi anak yang dididiknya. Oleh karenanya guru punya posisi sebagai manusia sumber dan punya peran strategis dan penting dalam pendidikan (Ghofar, 2017).

Sejalan dengan pendapat di atas, temuan di lapangan menegaskan bahwa untuk menjadi figur yang baik dan akan dicontoh oleh anak-anak, guru melakukan pembiasaan-pembiasaan rutin setiap hari seperti membuang sampah pada tempatnya, saling berbagi dengan teman, dan

98 mitra Ash-Shibyan: Jurnal Pendidikan dan Konseling | Vol. 4, No. 02 (2021) Licensed under CC-BY-SA c) (i) (2) 
memaafkan teman yang berbuat salah. Hal ini bertujuan agar anak percaya diri, dapat mengontrol diri, dan suka berbagi kepada sesama.

Pembiasaan positif yang dilakukan oleh orang dewasa, terlebih guru dan atau orang tua akan sangat membekas di ingatan anak, karena anak akan lebih percaya dengan apa yang ia lihat dan dengar Wiyani (2014). Sehingga ia lebih cenderung melakukan apa yang ia lihat dan dengar itu. Dengan demikian, orang tua atau pendidik PAUD harus dapat memberikan contoh perilaku yang baik secara langsung kepada anak, misalnya melakukan pembiasaan kepada anak (Marliani, 2015).

\section{Memberikan Kesempatan Kepada Anak untuk Melaksanakan Kegiatan Bermain Sosial}

Salah satu bentuk perhatian yang dapat guru lakukan adalah dengan memberikan fasilitas belajar yang cukup kepada anak (Jayanti dalam Hikmah, Syaprudin, \& Jannah (2021)). Dalam rangka memberikan fasilitas belajar kepada anak, guru memberikan kesempatan kepada anak untuk berinteraksi secara sosial dengan teman sebayanya. Dalam hal ini, guru dapat memberikan waktu untuk anak dalam memilih kegiatan permainan yang digemari, baik dilakukan pada saat belajar, jam pulang sekolah, dan hari tertentu yakni hari sabtu, agar anak dapat bersosialisasi baik dengan temannya. Wiyani (2014) mengatakan bahwa pada saat melakukan berbagai permainan tersebut, anak dapat berinteraksi dengan anak lainnya, mereka dapat saling bekerja sama, dan berusaha untuk mematuhi aturan yang berlaku.

Kegiatan bermain sosial yang dilakukan oleh anak akan sangat membantu anak dalam mencapai tugas perkembangan sosial-emosinya (Marliani, 2015). Sejalan dengan itu, Beaty (2013) menyatakan bahwa permainan merupakan alat utama bagi pengembangan sosial anak-anak. Lebih lanjut ia menegaskan, permainan mendorong interaksi sosial. Anakanak belajar bagaimana bermusyawarah, menyelesaikan konflik, menyelesaikan masalah, saling bergaul, mengambil giliran, bersabar, bekerja sama, dan berbagi. Ia menambahan, permainan juga membantu anak-anak memahami konsep keadilan dan persaingan. Jadi memberikan anak kesempatan untuk bermain dengan teman-temannya merupakan sesuatu yang sangat penting dilakukan dalam mengembangkan perkembangan sosial emosional anak. 
Faktor yang Mempengaruhi Perkembangan Sosial Emosional Anak Kelompok B TK As-Salam Pekan Arba Tembilahan

Dalam menumbuhkan dan mengembangkan potensi dan kemampuan yang dimiliki oleh anak usia dini, terutama anak kelompok B TK As-Salam Pekan Arba Tembilahan bukan perkara yang mudah. Hal ini disebabkan oleh berbagai macam faktor, diantaranya adalah fakor psikologi anak yang berbeda antara satu dengan yang lain, dimana anak merasa ingin menang sendiri dan tidak ingin berbagi dengan teman lainnya (egois). Akibatnya, suasana kelas menjadi ramai karena anak lainnya juga menginginkan hal sama. Sehingga, hal ini menyebabkan guru kesulitan untuk mengendalikan dan mengontrol kelas.

Selain itu, faktor kekompakan antar stakeholder dan saranaprasarana belajar memegang peran penting suksesnya kegiatan pengembangan sosial emosional anak usia dini, terutama anak kelompok B TK As-Salam Pekan Arba Tembilahan.

\section{SIMPULAN}

Guru sebagai orang tua kedua bagi anak di sekolah memegang peran penting dalam mengembangkan potensi dan kemampuan sosial emosial anak usia dini, terutama anak kelompok B TK As-Salam Pekan Arba Tembilahan. Karena, sosial emosional anak merupakan salah satu faktor penentu kesuksesan karir anak di masa medatang. Dengan kegiatan-kegiatan pembiasaan positif yang dilakukan oleh guru di sekolah, seperti pembiasaan rutin (salam, sapa, senyum), do'a bersama, pembiasaan spontan (pemberian pujian dan reward), kegiataan bermain sosial meliputi bermain bebas setiap hari sabtu, dan jam pulang sekolah mampu mengembangkan potensi dan kemampuan sosial emosional anak kelompok B TK As-Salam Pekan Arba Tembilahan. Pengembangan potensi dan kemampuan ini disertai dengan dua faktor utama, yaitu faktor internal dan faktor eksternal.

\section{DAFTAR PUSTAKA}

Admin. (2020, May 24). Ternyata, Kecerdasan Emosional Memegang Peran Penting dalam Kesuksesan Seseorang. Dipetik July 18, 2021, dari pipunpad: Pusat Inovasi Psikologi Universitas Padjajaran: https://pip.unpad.ac.id/postdetail/Ternyata-Kecerdasan-EmosionalMemegang-Peran-Penting-dalam-Kesuksesan-Seseorang

Beaty, J. J. (2013). Observasi Perkembangan Anak Usia Dini. Jakarta: Kencana. 
Djafar, F. A., Pasongli, H., Robo, T., \& Tolangara, A. (2020). Hubungan Antara Perhatian Orang Tua Terhadap Prestasi Belajar Siswa Dalam Bidang Studi Geografi Kelas VIII SMP Al-Irsyad Kota Ternate. Reforma: Jurnal Pendidikan dan Pembelajaran, 9(2), 61-65.

Fakhruddin, A. U. (2018). Sukses Menjadi Guru PAUD. Bandung: PT. Remaja Rosdakarya.

Ghofar, A. (2017). Guru: Digugu dan Ditiru. AL-MISHBAH, 05(1), 1-14. Dipetik July 19, 2021, dari http://journal2.uad.ac.id/index.php/almisbah/article/view/163

Hikmah, D., Syaprudin, D., \& Jannah, M. (2021). Hubungan Perhatian Orang Tua terhadap Kemandirian Anak Usia Dini di RA Jannatu 'Adn Purwakarta Tahun Ajaran 2019-2020. Paedagogie: Jurnal Pendidikan dan Studi Islam, 2(1), 19-31. doi:https://doi.org/10.52593/pdg.02.1.03

Khairiah, D. (2018). Assesmen Perkembangan Sosio-emosional Anak Usia Dini. Al Athfal, 1(1), 1-22.

Khaironi, M. (2018). Perkembangan Anak Usia DIni. Jurnal Golden Age Hamzanwadi University, 3(1), 1-12.

Latif, M., \& dkk. (2013). Orientasi Baru Pendidikan Anak Usia Dini. Jakarta: Kencana.

Marliani, R. (2015). Psikologi Perkembangan. Bandung: Pustaka Setia.

Mukhlis, A., \& Mbelo, F. H. (2019). Analisis Perkembangan Sosial Emosional Anak Usia Dini Pada Permainan Tradisional. PRESCHOOL: Jurnal Perkembagan dan Pendidikan Anak Usia Dini, 1(1), 11-28.

Nuraeni. (2014). Pendidikan Karakter Pada Anak Usia Dini. Jurnal Paedagogy, 1(2), 1-9.

Puspitasari, R. (2015). Pengaruh Pemberian Hadiah (Reward) Terhadap Kemandirian Belajar Anak di TK Tunas Muda Karas Kabupaten Magetan TA 2015/2016. Prosiding Seminar Nasional Pendidikan (hal. 53-55). Surakarta: Universitas Sebelas Maret Surakarta dan ISPI Wilayah Jawa Tengah.

Sukatin, Qomariyyah, Horin, Y., Afrilianti, A., Alivia, \& Bella, R. (2019). Analisis Psikologi Perkembangan Sosial Emosional Anak Usia Dini. Bunayya: Jurnal Pendidikan Anak, VI(2), 156-171.

Susanto, A. (2011). Perkembangan Anak Usia Dini. Jakarta: Kencana.

Sutarman, M., \& Asih. (2016). Manajemen Pendidikan Usia Dini. Bandung: CV. Pustaka Setia.

Syafi'i, I., \& Solichah, E. N. (2021). Asessmen Perkembangan Sosial Emosional Anak Usia Dini di TK Ummul Quro Talun Kidul. Jurnal Golden Age, Universitas Hamzanwadi, 53-88. doi:https:// doi.org/10.29408/jga.v5i02.3106

Wiyani, N. A. (2014). Psikologi Perkembangan Anak Usia Dini. Yogyakarta: Penerbit Gava Media.

Wulandari, H., \& Purwanta, E. (2021). Pencapaian Perkembangan Anak Usia Dini di TK Selama Pembelajaran Daring Saat Pandemi Covid-19. Jurnal Obsesi: Jurnal Pendidikan Anak Usia Dini, 5(1), 452-462. doi:10.31004/obsesi.v5i1.626 
Perkembangan Sosial dan Emosional Anak Usia Dini

Yusuf, S. (2016). Psikologi Perkembangan Anak \& Remaja. Bandung: PT. Remaja Rosdakarya. 